\title{
Study on the Application of Green Accounting Based on Corporate Social Responsibility in Kupang City
}

\author{
Puteri Ayu Pratiwi*, Rosdiana Mata, Rosmiati \\ Accounting Department \\ Kupang State of Polytechnic \\ Kupang, Indonesia \\ *puteriayu.pratiwi@gmail.com,ody.smart@gmail.com,rosmiati99@gmail.com
}

\begin{abstract}
This study aims to compare awareness, responsibility, reporting, and auditing of green accounting based on corporate social responsibility between the electricity industry and the trading industry in Kupang City. The research design in this study used a quantitative descriptive approach. In this study, sampling used was 50 people consisting of managers and staff in the accounting and CSR divisions. The data analysis techniques were the independent sample T-test and the Mann Whitney Utest. The results show that the hypothesis suggested in this study is rejected, meaning that there is no difference in green accounting awareness, green accounting responsibility, green accounting reporting, auditing green accounting based on corporate social responsibility in the electricity industry, and the trading industry.
\end{abstract}

Keywords-green accounting, corporate social responsibility, environmental accounting

\section{INTRODUCTION}

The Medium-Term Development Plan for the City of Kupang for the period 2017-2022 has one of the priority tasks in fourth position, namely the preparation of Kupang City to become an environmentally sustainable Metropolitan City with strategies and policy directions, namely the sustainability of the physical environment, strategic planning that complies with legal principles, the beauty of the city, the ecosystem, and urban quality with good hygiene. Environmental problems in Kupang City hold a strategic role in sustainable growth, with the concept of satisfying current needs without compromising the fulfilment of potential generations. Lako [1,2] stated that environmental problems are factors that become a competitive advantage for companies. The public and staff are responsive to environmental issues. Corporations identified as green corporations earn good support from stakeholders, and there are four progressive levels of corporate environmental responsibility, namely green accounting awareness, green accounting responsibility, green accounting reporting, and green accounting auditing. Radyati [3] concluded that corporations pay attention to environmental issues that deserve to increase long-term financial results by maximizing the company's reputation to stakeholders. Firstly, optimizing environmental performance requires a concept of environmental sustainability, one of which is green accounting, better known as environmental accounting.

Purnamawati [4] explained that Green Accounting or Environmental Accounting is a field of accounting that functions to identify, measure, assess, and report environmental accounting. Waste management that is carrying out includes the calculation, estimation, analysis, and monitoring of the costs of waste management from the company's operations' performance. The application of environmental accounting also helps assess how many environmental costs are high in waste management by using an accounting system to reduce the organization's costs and monitor corporate responsibility for environmental protection across the industry.

The application of green accounting based on corporate social responsibility has started to take effect in Indonesia. Changes in the business's paradigm and focus, take into view all stakeholders, affect the position of corporate social management, which is called corporate social responsibility. Corporate social responsibility is essentially a corporate process that voluntarily integrates its responsibility for the environment and society into its activities and interactions with stakeholders within the company's legal duties. Considering that Kupang City is an urban region and low in natural resources, only the secondary industrial sector has observed significant economic development. The economic sector's contribution to the Gross Regional Domestic Product of Kupang City in 2012-2016, with an average positive growth of 18,84 percent in the secondary sector, namely the electricity sector, while the average positive growth in the tertiary sector was 0.005 percent. That is the trading sector. The biggest possible challenge to this sector's growth is waste and toxic and industrial waste in Kupang City.PT PLN Persero East Middle south Nusa regions, the electricity industry's environmental responsibility, controls B3 and non-B3 waste and solid waste. In contrast, Ramayana Kupang, the corporate sustainability responsibility trading industry, has problems in processing inorganic waste and blurry liquid waste. It looked terrible in the storm drains of the current trading conditions.

Dewi [5] stated that an enterprise could be classified as contributing to environmental protection if it has environmental 
awareness, accompanied by environmental responsibility and environmental reporting, which is then optimized by environmental audit activities to assess and analyse organizational efficiency. Susilo [6] research has shown no difference in green accounting awareness and that there are differences in the roles of green accounting responsibility, green accounting reporting, and green accounting audits between Sleman and Bantul Regencies. After that, Sari's [7] found no differences in green accounting awareness, green accounting reporting, green accounting audits, and green accounting responsibility differences between Semarang universities. Astuti [8] showed that there were no differences in green accounting awareness, green accounting responsibility, green accounting reporting, and differences in green accounting audits between universities in the Yogyakarta and Surakarta regions. Endah's [9] between the mining industry and the metal industry showed no differences in green accounting awareness, green accounting responsibility, green accounting audits, and green accounting reporting differences. Artani [10] between local chain management Hotel and international chain management Hotel in Bali suggests no difference in green accounting awareness and that there are differences in green accounting responsibility, green accounting reporting, and green accounting audits.

There is a difference in this analysis's findings, including the presence of a research gap that the researcher wants to research. The research results on the application of green accounting based on corporate social responsibility have often shown different results. Therefore, further research is needed to provide information on green accounting based on corporate social responsibility in Kupang City. The purpose of this analysis is to recognize and provide information on the differences in the application of green accounting based on corporate social responsibility in the electricity and trading industries. Another advantage of green accounting based on corporate social responsibility is that it will build green industries that are economically sustainable and do not change the environment. It also deals with the survival of the organization. Four hypotheses have been used in this analysis, such as:

- Hypothesis 1: There is a difference in green accounting awareness based on corporate social responsibility comparison between the electricity industry and the trading industry.

- Hypothesis 2: There is a difference in green accounting responsibilities based on corporate social responsibility comparison between the electricity industry and the trading industry.

- Hypothesis 3: There are differences in green accounting reporting based on comparative corporate social responsibility between the electricity industry and the trading industry.

- Hypothesis 4: There are differences in green accounting audits based on comparative corporate social responsibility between the electricity industry and the trading industry.

\section{RESEARCH METHODS}

This study uses a research design that is a quantitative descriptive approach [11] that focuses on actual problems and phenomena that are happening at the moment in the form of research results in the form of numbers that have meaning. This study's populations were all managers and staff of PT PLN Persero East Middle south Nusa regions, the electricity industry, and Ramayana Kupang, the trading industry. The sampling technique in this study used a purposive sampling method, namely sampling using specific criteria (purposely).

These certain criteria are people who work in managing finance and CSR, have a minimum educational background of a bachelor's degree, and have at least one year of work experience. A sample size of 50 people consists of the finance and CSR divisions of PT PLN Persero, East Middle south Nusa regions, and Ramayana Kupang. This type of research data uses primary data from observations, questionnaires, and interviews with interested parties such as sector managers, CSR managers, or representatives. The questionnaire is taking from Endah's previous research [9]. The questionnaire is in the form of questions that must be answered by the respondent. Where the assessment is on a Likert scale 1-5 with the following details: $1=$ strongly disagree $($ STS $), 2=$ disagree $(\mathrm{TS}), 3=$ doubt (TS), 4 = agree (S), $5=$ strongly agree (SS). While, secondary details from the 2019 CSR Report, 2019 Corporate Financial report, research journals / theoretical studies relevant to the analysis carried out were collected.

The research variables are consisted of:

- Green Accounting Knowledge with the following indicators: a) The presence of environmental regulations; b) The philosophy of top managers; c) Suggestion from other industry associations; d) Suggestion from individual himself; e) Suggestions from the Labor Union; f) Consumer suggestions; g) Suggestions from conservation agencies; h) Suggestions from the Labor public sector union.

- Green Accounting Responsibility for the following indicators: a) The cost of raw materials for environmental services or goods; b) The provision of sufficient expenses of human and economic resources relevant to environmental responsibility; c) The availability of funds for the management of corporate waste.

- Green Accounting Reporting of the following indicators: a) There are costs for environmental activities; b) There are environmental aspects to be taken into account in investment or exchange decisions; c) Considerations of environmental factors, customers and other stakeholders affect the nature of costs for the product design process; d) Often support the achievement of sustainable profit growth. 
- Green Accounting Audits have the following indicators: a) Has audited regular financial accounts regularly; b) Has audited the efficiency of the business in regards to environmental quality and safety; c) The findings of the audit report are taken into account by the organization in carrying out its operations.

Techniques for the data analysis used in this study [12,13]:

- Test validity and reliability test. The Validity Test aims to assess the degree to which a measuring instrument is reliable and reliable in carrying out its measuring role. The minimum criterion to be assumed to be true is whether $r$ is $\geq$ other than the coefficient in the essential values table $\mathrm{r}$, which is at a substantial amount of $5 \%$ or $1 \%$. Reliability tests assess the degree of freedom of measurement against random errors and thus generate a steady form or, in other terms, to see whether or not the measuring device used is reliable. The unit is said to be accurate if it has a Cronbach Alpha value greater than 0.6 .

- Test Normality. The normality Concept is a condition for most inferential statistical procedures. The normality test object is to test whether or not independent variables, independent variables, or both have a normal distribution in a regression model. The reasonable regression model is a normal or almost normal distribution. Detection of normality by looking at the sig value of each statement. The basis of decisionmaking is as follows: The test is not normal, but the test hypotheses use the Mann Whitney U-Test if the sign value is below 0.005 . If the value exceeds 0.005 the test is normal, and then the hypothesis is tested with the Independent T-test sample.

- Difference Test. The Independent Sample T-Test is used to test this hypothesis if the data are normally distributed. The decision-making criteria are used for the Mann Whitney test if the significant value is $>0.05$, the proposed hypothesis means rejected, and if the significant value is $<0.05$, the proposed hypothesis means accepted.

\section{RESULTS}

The validity test of SPSS statistics 21 software obtains test results that all question items are valid because each item is corrected item-total Correlation value has a value greater than the minimum standard (0.284). The results of the validity test show that all the calculated $r$ values are more generous at the $5 \%$ significant value is 0.284 . Then it can be stated that all items in this questionnaire are valid. Reliability data can be found shows that all questionnaire items with a consistency level between $0.707-0.902$ and declared reliable. Table 1 shows the results of the Normality test as follows:
TABLE I. NORMALITY TEST RESUlTS

\begin{tabular}{|c|c|c|}
\hline Indicator & Sig & Inf \\
\hline $\begin{array}{l}\text { Green } \\
\text { Awareness }\end{array}$ & 0.324 & Data is normally distributed \\
\hline $\begin{array}{l}\text { Green Accounting } \\
\text { Responsibility }\end{array}$ & 0.019 & Data are not normally distributed \\
\hline $\begin{array}{ll}\text { Green } & \text { Accounting } \\
\text { Reporting } & \\
\end{array}$ & 0.027 & Data are not normally distributed \\
\hline Green Accounting Audit & 0.000 & Data are not normally distributed \\
\hline
\end{tabular}

The results of the Difference Test presented in Table 2 are as follows:

TABLE II. COMPARISON OF GREEN ACCOUNTING AWARENESS RESUlTS WITH INDEPENDENT SAMPLE T-TEST

\begin{tabular}{|l|l|l|l|l|}
\hline \multicolumn{1}{|c|}{ Information } & T count & Mean & Sig (2 tailed) & Status H1 \\
\cline { 1 - 3 } Electricity Industry & 0.220 & 34.64 & 0.827 & \multirow{2}{*}{ rejected } \\
\hline Trade Industry & 0.220 & 34.48 & & \\
\hline
\end{tabular}

Table 2 shows that the test results of Hypothesis 1 with a sig value of 0.827 mean that there is no difference in green accounting awareness based on corporate social responsibility, the comparison between the electricity industry and the trading industry, so the hypothesis is rejected.

TABLE III. COMPARISON OF GREEN ACCOUNTING RESPONSIBILITY RESULTS WITH MANN WHITNEY U-TEST

\begin{tabular}{|l|l|l|l|}
\hline \multicolumn{1}{|c|}{ Information } & Mean & Sig (2 tailed) & Status H2 \\
\cline { 1 - 2 } Electricity Industry & 26.12 & 0.752 & \multirow{2}{*}{ rejected } \\
\hline Trade Industry & 24.88 & & \\
\hline
\end{tabular}

Table 3 shows that the results of testing hypothesis 2 with a sig value of 0.752 mean that there is no difference in green accounting responsibility based on the comparison of corporate social responsibility between the electricity industry and the trading industry, so the hypothesis is rejected.

TABLE IV. COMPARISON OF GREEN ACCOUNTING REPORTING RESULTS WITH MANN WHITNEY U-TEST

\begin{tabular}{|l|l|l|l|}
\hline \multicolumn{1}{|c|}{ Information } & Mean & Sig (2 tailed) & Status H3 \\
\hline Electricity Industry & 24.68 & 0.683 & \multirow{2}{*}{ rejected } \\
\cline { 1 - 2 } Trade Industry & 26.32 & & \\
\hline
\end{tabular}

Table 4 shows that the results of testing this hypothesis 3 with a sig value of 0.683 mean that there is no difference in reporting on green accounting based on the corporate social responsibility comparison between the electricity industry and the trading industry. The hypothesis is rejected.

TABLE V. COMPARISON OF GREEN ACCOUNTING Audits RESUlts WITH MANN WHITNEY U-TEST

\begin{tabular}{|l|c|c|l|}
\hline \multicolumn{1}{|c|}{ Information } & Mean & Sig (2 tailed) & Status H4 \\
\hline Electricity Industry & 25.58 & 0.965 & \multirow{2}{*}{ rejected } \\
\cline { 1 - 2 } Trade Industry & 25.42 & & \\
\hline
\end{tabular}


Table 5 shows that testing hypothesis 4 with a sig value is 0.965 , which means that there is no difference in green accounting audits based on corporate social responsibility comparison between the electricity industry and the trading industry, so the hypothesis is rejected.

\section{DISCUSSIONS}

The context in which the test results state that the first hypothesis is rejected this supports the research conducted by Susilo [6], Sari's [7], Astuti [8], Endah's [9], Artani [10]. They compared different industrial corporations, medical corporations, hotels and universities. This empirical test shows that there is no difference in green accounting awareness based on corporate social responsibility compared to the electricity industry and the trading industry. The State Electricity Enterprise also has environmental regulations that encourage CSR activities, including Directors Regulation No 0138 of 2019 on the rules for corporate social responsibility based on ISO 26000. The philosophy communicated to stakeholders on the energy-saving culture would help to protect the Earth and the next century from environmental harm. Ramayana Kupang management advises customers to carry in bags crafted from environmentally sustainable products, which is a type of waste management. The two manufacturing firms are also organizing numerous CSR initiatives with WALHI, the Kupang City national environment Community and the Industry Worker Union. The result of testing hypothesis 2 regarding green accounting responsibility states that the hypothesis is rejected, which means that there is no difference in green accounting responsibility based on corporate social responsibility. These results support the research conducted by Endah's and Astuti on the comparison of industrial companies and the comparison of universities. The responsibility of green accounting based on corporate social responsibility which is implemented by the State Electricity Enterprise and Ramayana Kupang must carry out a commitment to protect the environment for waste for the company's operational activities. The two companies carry out CSR programs related to the environment assisting public facilities and training to community groups to recycle waste into products that can provide more benefits than waste and provide assistance, including clean sanitation and city parks. The results of hypothesis 3 state that the hypothesis is rejected, which means that there is no difference in green accounting reporting based on corporate social responsibility in the comparison of the electricity industry with the trading industry. This result supports the research conducted by Astuti and Sari's, both of whom researched university areas in Indonesia. The State Electricity Company and Ramayana Kupang in its 2019 CSR report present the company's activities in providing facilities and training assistance where $5 \%$ of the increase in company profits per year contributes to the company's CSR funds. The company's financial statements explain environmental costs, including the management and maintenance of related waste. In the test results regarding the green accounting audit, it states that the hypothesis 4 is rejected, which means that there is no difference in green accounting audits based on corporate social responsibility in the comparison of the electricity industry and the trading industry. These results are supportive of Endah's and Sari's research conducted on industrial company comparisons and university comparisons. The State Electricity Enterprise and Ramayana Kupang conduct annual audits of financial reports as well as audits of environmental performance.

\section{CONCLUSiOnS AND SugGestions}

This study concludes that the results of testing hypothesis 1 are rejected with a sig value of 0.827 , meaning that there is no difference in green accounting awareness based on corporate social responsibility compared to the electricity industry and the trading industry. Hypothesis 2 testing results are rejected with a sig value of 0.752 , meaning that there is no difference in green accounting responsibility based on corporate social responsibility compared to the electricity industry and the trading industry. The hypothesis testing 3 results are rejected with a sig value of 0.683 , meaning that there is no difference in green accounting reporting based on corporate social responsibility compared to the electricity industry and the trading industry. The results of testing hypothesis 4 are declared rejected with a sig value of 0.965 , meaning that there is no difference in green accounting audits based on corporate social responsibility in comparing the electricity industry with the trading industry. This study suggests that corporations should improve their commitment to green accounting based on corporate social responsibility and develop innovative products and technologies that are environmentally sustainable and cost-effective in handling waste materials. Future research incorporating other variables linked to green accounting for which empiric tests have never become conducted out.

\section{ACKNOWLEDGMENT}

We want to thank the Director of the Kupang State Polytechnic, the Head of the Kupang State Polytechnic Community Service and Study Centre, the Head of the Kupang State Polytechnic Accounting Department, all the managers and staff of PT PLN Persero East Middle south Nusa regions, and all the managers and staff of Ramayana Kupang.

\section{REFERENCES}

[1] A. Lako, Green Economy: Menghijaukan Ekonomi, Bisnis, dan Akuntansi, Jakarta: Erlangga, 2015.

[2] A. Lako, Akuntansi Hijau: Isu, Teori dan Aplikasi, Jakarta: Salemba Empat, 2018.

[3] M.R.N. Radyati, Sustainable Business dan Corporate Social Responsibility (CSR), Jakarta: CECT Trisakti University, 2014

[4] I.G.A. Purnamawati, Green Accounting: A Management Strategy and Corporate Social Responsibility Implementation. International Journal of Community Service Learning, vol. 2, no. 3, pp. 149-156, 2018.

[5] S.R. Dewi and E. Maryanti, Penerapan Green Accounting Berbasis University Social Responsibilty Di Universitas Muhammadiyah Sidoarjo, 2017.

[6] J. Susilo, "Green Accounting Di Daerah Istimewa Yogyakarta Stud Kasus: Antara Kabupaten Sleman Dan Kabupaten Bantul.Accounting 
Department Faculty of Business and Economics Islamic University of Indonesia," Jurnal Akuntansi dan Auditing Indonesia, 2008.

[7] H. Sari, "Pengawasan Impelementasi Green Accounting Berbasis University Social Responsibilities Di Universitas Negeri Semarang Serta Studi Komparasi Universitas Se-kota Semarang," Jurnal Akuntansi dan Auditing, vol. 9, no. 2, 2013.

[8] F. Astuti, Analisis Penerapan Green Accounting Berbasis University Social Responsibilty Studi Komparasi: Pada Perguruan Tinggi di Wilayah Yogyakarta dan Surakarta, 2017.

[9] Y. Yudi, "Analisis Komparasi Penerapan Green Accounting (Studi Kasus Pada Industri Batubara dan Industri Logam Tahun 2014-2016)," Jurnal Akuntansi \& Keuangan Unja, vol. 3, no. 4, pp. 9-18, 2018.
[10] K. Artani, "Green Accounting Pada Local Chain Management Hotel dan Pada Internasional Chain Management Hotel Di Bali," Jurnal Riset Akuntansi dan Bisnis Airlangga, vol. 4, no. 2, 2019.

[11] I. Ghozali, Analisis Multivariate dengan Program IBM dan SPSS Semarang: BP Universitas Diponegoro, 2011.

[12] H. Jogiyanto,Metode Penelitian Bisnis, Yogyakarta: Universitas Gadjah Mada, 2014.

[13] Sugiyono, Metode Penelitian Kombinasi (mixed methods), Bandung: Alfabeta, 2015. 